International Journal of Soft Computing 6(4): 119-127, 2011

ISSN: $1816-9503$

(C) Medwell Journals, 2011

\title{
An Internet Based Instructional Design Framework for Vocational Education
}

\author{
${ }^{1}$ Thosporn Sangsawang, ${ }^{2}$ Kalayanee Jitgarun and ${ }^{3}$ Paiboon Kiattikomol \\ ${ }^{1}$ Learning Innovation in Technology Program \\ ${ }^{2}$ Department of Electrical Technology Education, \\ Faculty of Industrial Education and Technology, \\ ${ }^{3}$ Executives Project of Media Arts and Media Technology Curriculum, \\ King Mongkut's University of Technology, Thonburi Bangkok, Thailand
}

\begin{abstract}
Internet based courses has become a dominant factor in instructional, academia and everyday life. It has increasingly been developed by many academic institutions, organizations and companies worldwide due to their benefits for both learners and educators. However, many of the developmental approaches lack two important considerations needed for implementing internet-based instructional applications such as integration of the psychologies learning theories with instructional design and development of the process and evaluation framework to improve the overall quality of internet-based learning support vocational education. This study addressed these two weaknesses while developing based on a vocational education environment. Thus, the purpose of this study was to synthesize an instructional design framework from mental process, learning by doing and social context, to create an internet based instructional design framework for vocational education. The framework was created by synthesizing three existing theories of instructional design. To synthesize the framework first used the Delphi technique with 17 experts to identify their perspectives on the three instructional design theories. The results revealed that the framework provides excellent potential for develop and evaluation. The process is easy, effective access to information and also implies an integrated performance of development method. The study also confirmed that for an internet-based instructional to be successful, various aspects of the online environment should be considered such as application domain knowledge, conceptual theory and evaluation about the overall quality of the design environment.
\end{abstract}

Key words: Instructional design internet based instructional, vocational education, cognitive flexibility, social content, Thailand

\section{INTRODUCTION}

As an increasingly powerful interactive and dynamic medium for delivering information, the World Wide Web (Web) in combination with information technology has found many applications. One popular application has been for educational use such as Web-based, distance, distributed or online learning. The use of the Web as an educational tool has provided learners and educators with a wider range of new and interesting learning experiences and teaching environments, not possible in traditional in class education. Internet based learning environments have been developed mainly by instructional designers using traditional instructional design models such as the instructional systems design, cognitive flexibility theory and constructivist learning environment (Dick and Carey, 1996; Jonassen, 1983). However, many of these approaches still lack two important considerations needed for implementing learning applications based on the Web: integration of the learner participant with instructional design and social context, development of the process and evaluation framework to improve the overall quality of internet-based learning support vocational education.

This study addressed these two weaknesses while developing based on a vocational education environment. This research was to synthesize an instructional design framework from mental process, learning by doing, social context and to create an instructional design framework for vocational education. As The National Education Act (1999) which read: In organizing the learning process, educational institutions and agencies concerned shall provide training in thinking process, management, how to face various situation and application of knowledge for obviating and solving problems. This is to make Thai

Corresponding Author: Thosporn Sangsawang, Learning Innovation in Technology Program,

Faculty of Industrial Education and Technology,

King Mongkut's University of Technology, Thonburi Bangkok, Thailand 
learners capable to develop their own self and compete with the world's knowledge-based economy. Moreover, Section 66 also reads learner shall have the right to develop their capabilities for utilization of technologies for education as soon as feasible so that they shall have sufficient knowledge and skills in using these technologies for acquiring knowledge themselves on a continual lifelong basis. This is to make Thai learners capable to use technology for seeking knowledge (Sangsawang, 2006).

Since, learners in the past rely on teachers in the classroom for their study, online learning demands more self-regulation and discipline from learners. As such, teachers need to come into center stage to guide their learners and such action might be different from the ideal sheer supervision and facilitation (Cobb and Steffe, 2011). To reflect on the current issue about the online learning which requires self-regulation from learners, researchers think of ways which can comply with the learner-based pedagogy in Thai education environment with the hope to achieve instructional model for teachers and educators in dealing with such issue. It is the fact that any instructional design model is intended to prepare learners for the world of work and link (s) competence and competency to performance. Both competence and competency are derived from professional standards which are essential to what learners are required to do. Courses in vocational education provide learners with opportunities and experience in hands-on learning (Conroy and Walker, 2000). When E-learning is introduced to vocational education, practical or hands on elements are transformed into conceptual understanding (Velde and Cooper, 2000). Students can neither see nor touch the elements of their subject. When teachers introduce abstract concepts into vocationally based learning (Attwell, 1997) there can be erroneous notions about the concepts taught in class when only traditional materials are available (Marr et al., 1999).

Therefore, electronic media in technology-enhanced, student-centered learning environments can facilitate learning and understanding of abstract concepts due to the fact that students can notice graphically displayed changes of concrete experience (Hannafin and Land, 1997; Alexander, 2001). Effective e-learning environments allow students to work socially with each other, the teacher is present, printed resources are available and students interact purposively with the computer (Phillips, 2005).

In fact, vocational education needs both academic and practical approaches. Each style requires different instructional design framework. There are three frameworks of E-learning we will examine in this study: mental processes, learning by doing and social context.
With these three models as the guide, we have developed a questionnaire to submit to educational experts. Using the Delphi method, we have synthesized these three methods in order to create a new method for online vocational training. This method will be applied to teaching online vocational arts.

Theoretical frameworks are a myriad of ways in which internet based educational practicums may be utilized based upon the instructional and pedagogical needs of the vocational course. The development of instructionally effective online learning environments that meet these pedagogical needs requires the application of appropriate instructional design principles. When designing online instruction, the underlying pedagogical philosophy and application of learning theories including constructivism and constructionism will influence decisions regarding what instructional strategies may be adopted (Dick and Carey, 1996).

In this research is focus three theories also include about as learning theories in mental processes, learning by doing and social context all theories psychologies learning as following: Mental processes, learning by doing and social context. Therefore, the researcher would like to synthesize three theories mentioned above by using Delphi technique so that experts express their opinion on what they agree to create an instruction framework that complies with psychological principles according to instructional design framework for autonomy. This framework will be help learners achieve learning objectives with effectiveness and efficiency as well as to help learners understand in a faster and stable way (Sangsawang, 2006). Finally, relationships between the design process framework and the effectiveness of the internet-based environment will be given.

Literature review: This study develop framework based on three theories also include about as learning theories in mental processes, learning by doing and social context all theories psychologies learning as following:

Mental processes theories: The way of many thinking of experts' idea there is focus on mental processes from this ways in which thoughts occur to the ways in there are behaviorism arose from mental processes this system examines the outcomes or behaviors of learning. Instructional design, there is applicable to cognitive, behavioral and attitudinally learning as in cognitive strategies, according to create understanding (Taylor, 1996), applicable in cognitivist (Merriam and Caffarella, 1991) for create situated cognition and following in elements of situated cognition, building on 
cognitive or mental phenomenon, cognitive activity (Jetin, 2006) and cognitive organizers (Tan et al., 2008) with in cognitive structure and the operate of processes of memory. The mental processes of this instructional design framework, there is applicable to cognitive, behavioral and attitudinally learning. Therefore, in example as a micro theory, it provides a set of procedures to follow for each instructional event to enhance learning. The learning processes identify nine events of instruction which are tied to cognitive strategies learning theory. Note that the first event in the theory of instructional design framework is attention which parallels that of cognitive strategies learning theory. The next event, informing of the objectives, further activates a process of getting the trainees attention focused. Stimulating recall of requisite learning ties into activation of memory. Let's examine the nine events of instruction in more detail. As we do so, we will refer back to relevant sections of social learning theory for additional information (Blanchard and Thacker, 2007). Gagnei (1985) developed a 9 step process called the events of construction. These detail how an instructional event corresponds with an internal mental process in the learner. The interactive content in an e-learning course can keep the learners' attention as described in Gagnei (1985)'s nine events of instruction (Muzio et al., 2002).

Learning by doing theories: The most popular and effective process of learning ever adopted by psychology and teaching learning process is through learning by doing. In these learning processes the activity based on practical activities for creating skills for occupations or vocation. There is reference to experience in group participant of techniques or technology. There is a focus on constructivist learning theory, the ways of doing and thinking (Piaget, 1972) and humanist (Merriam and Caffarella, 1991) in which thoughts occur to the research is agreeable that learning by doing which focuses on knowledge construction based on the learner's previous experience is a good fit for E-learning (Harman and Koohang, 2005; Hung, 2001; Koohang and Harman, 2005). Entrenched in learning processes theories advanced by Deway (1933), Piaget (1972) and Bruner (1990) constructivism learning theory is defined as active construction of new knowledge based on a learner's prior experience (Koohang et al., 2008). Woolfolk said about states the following as in The key idea is that students actively construct their own knowledge: the mind of the student mediates input from the outside world to determine what the student will learn. Learning is active mental work, not passive reception of teaching (Koohang et al., 2008). Honebeins advanced set of goals aid the design of constructivism in learning settings. These have seven goals (Provide experience with the knowledge construction process, provide experience in and appreciation for multiple perspectives, embed learning in realistic and relevant contexts, encourage ownership and voice in the learning process encourage ownership and voice in the learning process, embed learning in social experience, encourage the use of multiple modes of representation and encourage self-awareness in the knowledge construction process) (Honebein, 1996).

Social context theories: There is focus on constructionism knowledge-building, situating constructionism, social and situation (Bandura, 1986), (Merriam and Caffarella, 1991), situated learning, social negotiation; social constructionism and constructivism, social contexts, social work and teaching or experiential learning from this ways in which thoughts occur to the ways in a theory of learning as well as a system for educational development. It builds upon but argues that there must be a social context in order for the learner to build and develop his ideas (Kafai and Resnick, 1996). You must create an idea. It cannot be transmitted to you by a teacher, peer or book. You make your idea. Constructionism then adds to this fundamental notion that knowledge is constructed more effectively when you are engaged in the construction of personally meaning ful products. In constructionism, the effect of is as important as gaining knowledge. When placed in the context of vocational internet based training, the curriculum must be carefully designed to incorporate the learner and excite in him the desire for the outcome. The training that occurs online should foster a desire to make meaningful online tools. Otherwise, it is argued, the learner will not engage. Social an instructional design model is intended to prepare learners for the world of work and link (s) competence and competency to performance. Both competence and competency are derived from professional standards which are essential to what learners are required to do. Courses in vocational education provide learners with opportunities and experience in hands-on learning (Conroy and Walker, 2000; Velde and Cooper, 2000). When E-learning is introduced to vocational education, practical or hands on elements are transformed into conceptual understanding. Students can neither see nor touch the elements of their subject. When teachers introduce abstract concepts into vocationally based learning (Attwell, 1997) there can be erroneous notions about the concepts taught in class when only traditional materials are available (Marr et al., 1999). 


\section{MATERIALS AND METHODS}

This study was to synthesize an instructional design framework from mental process, learning by doing and social context, to create an internet based instructional design framework for vocational education. These data were used to conduct analyses to develop valid and reliable perceived attribute measures.

\section{Sample group (Part I)}

To synthesize an instructional design framework: Sampling group was composed of samples were 17 experts chosen through purposive sampling method. Seven experts were qualified in educational psychology and ten in educational technology. They all had a doctoral degree and had worked for $>5$ years with at least the position of Assistant Professor. Selected by purposive sampling method.

\section{Part II}

To create an instructional design framework for Vocational level: Samples were 100 instructors who they are chosen through purposive sampling method and they developed electronics media in vocational education fields.

Data analysis: An initial study was conducted with experts and instructors. The survey was on a 5-point Likert-type scale. Data collection was done by questionnaires then, the questionnaires were analyzed to find out the conclusion. Data analysis was done using SPSS/FW (Statistic Package for Social Science/for Windows) software. The part with selection items was analyzed using frequency and percentage. The part with five scales was analyzed using mean (X) Standard Deviation (SD) and Correlation. The levels of agreement from respondents were as follows: Average score 1.00-1.49 means strongly disagree until 4.50-5.00 means definitely agree.

Research methods: The operation has been done from three types of tools; it has faced several problems as there was used the Delphi technique procedure. This research will study about the operation of this study by the following methods: Brainstorming, evaluation and reevaluation.

Brainstorming: Researchers sanded semi-structured interviews utilized to 17 experts for first round: brainstorming of opinions' experts would be related to framework from mental processes, learning by doing and social context.
Researchers' analyzed interviews were opinions' expert towards each idea through questioning. The details of the interview form would be as follows: four parts as following in: key ideas principles, teaching-learning activities strategies, teaching-learning environments, stages of instructional sequence.

Researchers synthesized opinions' experts for the questionnaire that it's using a Likert (1932)'s five-rating scale. After that, I was an instructional design framework from mental processes, learning by doing and social context.

Evaluation: Researchers would be evaluation of the ideas using a Liker's five-rating scale questionnaire for the second round as shown in evaluation of the 17 experts' ideas on mental processes, learning by doing and social context concerning an instructional design framework for vocational education.

Researchers' would select the items from the results of questionnaire I. It means that all key ideas principles, teaching-learning activities Strategies, teaching-learning environments, stages of instructional sequence. comprising from mental processes, learning by doing and social context would be pooled together as similarities or differences. The similarities meant that most of the 17 experts agreed while the differences meant in vice versa.

Researchers resulted of synthesis of similarities and differences would lead to diagram chart. Then, the 17 experts would be required to respond Yes or No to the questionnaire II.

Re-evaluation: Researchers would select the items from the results of questionnaire II It means that all key ideas principles, teaching-learning activities strategies, teaching-learning environments, 'stages of instructional sequence. Comprising from mental processes, learning by doing and social context.

Researchers would be pooled together as similarities or differences. The similarities meant that most of the 17 experts agreed while the differences meant in vice versa. The results of synthesis as conclude to questionnaire III. Researchers created an instructional design framework for Vocational education.

Researchers would be concerning an framework with sample of the study consisted of 100 instructors who developed electronics media (Such as e-Book and eLearning, WBI, CAI) in vocational education fields (As in electrical, electronics, civil and mechanics) from several the faculty of technical education of university in Thailand. Researchers conclude the questionnaire III. After that I was diffusion framework for Internet based Instructional Design Framework for Vocational Education. 


\section{RESULTS AND DISCUSSION}

The results in this research focus three cluster for creates framework from theories also include about the learning process. The study were according to experts opinions, similarities and differences could be described in framework as shown in three part as following:

\section{Part I}

The orientation learning theories: The orientation learning theories focuses in three theories as in mental processes, learning by doing, social context all theories psychologies as in key ideas principles, teaching/learning activities/strategies, teaching learning environments, stages of instructional sequence, teaching learning models.

Key ideas principles: From Table 1 the key ideas principles focus in mental processes (Understanding and memories: cognitive strategies in could internal mental phenomena, situated cognition, elements of situated cognition, cognitive structure, cognitive organizers, cognitive activity), learning by doing (Working and thinking: activity to fulfill potential strategies in could ways of doing and thinking, human act to social cognitive; active methods, share their knowledge and skill) and social context (Interaction and Activities social skill). Construct knowledge social strategies in could knowledge-building, social and situating constructionism, situated learning, social contexts, social work and teaching or experiential learning).

Table 1: The key ideas principles focus in mental processes, learning by doing and social context

Items Key ideas principles

Mental processes Understanding and memories (Cognitive strategies in could internal mental phenomena, situated cognition, elements of situated cognition, cognitive structure, cognitive organizers, cognitive activity)

Learning by doing Working and thinking (Activity to fulfill potential strategies in could ways of doing thinking, active methods, human act to social cognitive, share their knowledge and skill)

Social context Interaction and activities social skill (Construct knowledge social strategies in could knowledgebuilding, social and situating constructionism, situated learning, social contexts, social work and teaching or experiential leaming
Teaching/learning activities/strategies: From Table 2 the teaching/learning activities/strategies focus in mental processes (Creating condition internal mental learning process as in insight information, create processing memory, perception, provide situated cognition (Content, activities, performances processes access, support construction of knowledge, promote reflection and articulation for learning and teaching), learning by doing (Activities learning by doing their own self understanding of the course with learning by doing work and creating thinking together with ability to learn on his own and share their knowledge and skill through various types of method learning environment) and social context (Construction knowledge social strategies by social context that in could working social, discussing constructions, sharing constructions and creating wit' knowledge their own).

Teaching learning environments: From Table 3 the teaching learning environments focus in mental processes (Using education media: (Concept map, spider diagram, fishbone, structured overview and $\mathrm{T}$ chart and method learning: guide learner understands in practice and evaluation), learning by doing (Using action activities environments: interactions within a learning by doing process; share their knowledge and skill through various types of social, activity their opportunities to develop met cognitive knowledge about persons, tasks and strategies evaluate their learning by their own part of the total experience) and social context (Using interaction with social constructionists: experiential learning, perceptions of experience by their own understanding; construction their own to thinking of it as learning-by-making; actions their social learning; interaction and cognitive processes; interaction/observation in social contexts).

Stages of instructional sequence (Table 4): The stages of instructional sequence focus in mental processes, cognitive are shot-long-term memory strategies help learner store information into long-term memory by

Table 2: The Teaching/learning activities/strategies focus in mental processes, learning by doing and social context

\begin{tabular}{|c|c|c|}
\hline Mental processes & Learning by doing & Social context \\
\hline $\begin{array}{l}\text { Creating condition internal mental } \\
\text { learning process as in insight information }\end{array}$ & $\begin{array}{l}\text { Activities learning by doing their own self understanding } \\
\text { of the course with leaming by doing work }\end{array}$ & $\begin{array}{l}\text { Construction knowledge social strategies by } \\
\text { social context that in could working social }\end{array}$ \\
\hline Create processing memory & Creating thinking together with ability to leam on his own & Discussing constructions \\
\hline $\begin{array}{l}\text { Perception knowledge and } \\
\text { information }\end{array}$ & $\begin{array}{l}\text { Share their knowledge and skill through } \\
\text { various types of method learning environment }\end{array}$ & Sharing constructions \\
\hline $\begin{array}{l}\text { Provide situated cognition } \\
\text { (Content and activities) }\end{array}$ & Construction knowledge & Creating wit' knowledge their own \\
\hline $\begin{array}{l}\text { Performances processes access } \\
\text { (Dill and practices) }\end{array}$ & Activity, performances processes access (Act. and Games) & Working social \\
\hline Support construction of knowledge & Promote reflection and articulation for learning and teaching & \\
\hline
\end{tabular}


Table 3: The eaching learning environments focus in mental processes, learning by doing and social context

\begin{tabular}{|c|c|c|c|}
\hline Teaching learning environments & Mental processes & Learning by doing & Social context \\
\hline \multicolumn{4}{|l|}{ Using education media } \\
\hline Concept map & $\sqrt{1}$ & $\mathrm{X}$ & $\mathrm{X}$ \\
\hline Spider diagram & $\sqrt{1}$ & $\mathrm{X}$ & $\mathrm{X}$ \\
\hline Fishbone & $\sqrt{1}$ & $\mathrm{X}$ & $\mathrm{X}$ \\
\hline Structured overview & $\sqrt{1}$ & $\mathrm{X}$ & $\mathrm{X}$ \\
\hline $\mathrm{T}$ chart & $\sqrt{ }$ & $\mathrm{X}$ & $\mathrm{X}$ \\
\hline \multicolumn{4}{|l|}{ Using action activities envir onments } \\
\hline Interactions with in a learning by doing process & $\mathrm{X}$ & $\sqrt{t}$ & $\mathrm{X}$ \\
\hline Share their knowledge and skill through various types of social & $\mathrm{X}$ & $\sqrt{1}$ & $\mathrm{X}$ \\
\hline Activity their opportunities to develop met cognitive knowledge about persons & $\mathrm{X}$ & $\sqrt{1}$ & $\mathrm{X}$ \\
\hline Tasks & $\mathrm{X}$ & $\sqrt{1}$ & $\mathrm{X}$ \\
\hline Strategies evaluate their learning by their own part of the total experience & $\mathrm{X}$ & $\sqrt{ }$ & $\mathrm{X}$ \\
\hline \multicolumn{4}{|l|}{ Using interaction with social constructionists } \\
\hline Experiential learning & $\mathrm{X}$ & $\mathrm{X}$ & $\sqrt{1}$ \\
\hline Perceptions of experience by their own understanding & $\mathrm{X}$ & $\mathrm{X}$ & $\sqrt{1}$ \\
\hline Construction their own to thinking of it as leaming by making & $\mathrm{X}$ & $\mathrm{X}$ & $\sqrt{1}$ \\
\hline Actions their social learning & $\mathrm{X}$ & $\mathrm{X}$ & $\sqrt{1}$ \\
\hline Interaction and cognitive processes & $\mathrm{X}$ & $\mathrm{X}$ & $\sqrt{ }$ \\
\hline
\end{tabular}

Table 4: The stages of instructional sequence focus in mental processes, learning by doing and social context as following

\begin{tabular}{|c|c|c|}
\hline Mental processes & Leaming by doing & Social context \\
\hline Instructors creates stimuli activates receptors & $\begin{array}{l}\text { Learners rethinking to activate } \\
\text { pre-knowledge }\end{array}$ & $\begin{array}{l}\text { Learners and instructors share thinking of it as building } \\
\text { their own self- knowledge }\end{array}$ \\
\hline Instructors create level of expectation for learning & Learners find questions & $\begin{array}{l}\text { Learners and instructors building with structures to } \\
\text { construct their own self-constructionism }\end{array}$ \\
\hline $\begin{array}{l}\text { Instructor building retrieval and activation } \\
\text { of short-term memory }\end{array}$ & $\begin{array}{l}\text { Learner's self-regulation learning by } \\
\text { doing their tasks }\end{array}$ & $\begin{array}{l}\text { Learners and instructors construct knowledge } \\
\text {-building communities }\end{array}$ \\
\hline Instructors select perception of content & Learners share activities with other together & $\begin{array}{l}\text { Learners and instructors discuss and construct } \\
\text { knowledge organization }\end{array}$ \\
\hline $\begin{array}{l}\text { Instructors create semantic encoding for } \\
\text { storage long-term memory }\end{array}$ & $\begin{array}{l}\text { Learner share understanding knowledge } \\
\text { with instructor }\end{array}$ & $\begin{array}{l}\text { Learners and instructors share and construct } \\
\text { Information to knowledge management }\end{array}$ \\
\hline $\begin{array}{l}\text { Instructors glide how learners to do responds to } \\
\text { questions to enhance encoding }\end{array}$ & $\begin{array}{l}\text { Learners share regulating activities } \\
\text { knowledge transfer }\end{array}$ & $\begin{array}{l}\text { Learners and instructors construct and share working } \\
\text { and collaborating on constructs their own }\end{array}$ \\
\hline $\begin{array}{l}\text { Instructor create verification, (Reinforcement and } \\
\text { assessment of correct performance) }\end{array}$ & Learners present the activity & $\begin{array}{l}\text { Learners and instructors combine experience for } \\
\text { develop their own self }\end{array}$ \\
\hline
\end{tabular}

Instructors were retrieval and reinforcement of content as final evaluation of learning, and retrieval and generalization of learned skill for learner to building new situation

building new information with prior knowledge. These models is cognitive processes include: stimuli activates receptors, creates level of expectation for learning, retrieval and activation of short-term memory, selective perception of content, semantic encoding for storage long-term memory, responds to questions to enhance encoding and verification, reinforcement and assessment of correct performance, retrieval and reinforcement of content as final evaluation, retrieval and generalization of learned skill to new situation. Learning by doing (Critical thinking strategies help learners applying previous knowledge, create new situations and solve problems. These models is learning by doing include: activate preknowledge, find questions (Self-regulation learning by doing their tasks and activities, planning activities (Goal setting, task analysis, activities, comprehending and understanding knowledge regulating activities and knowledge transfer, make simple charts diagrams or tables make organize course).

Teaching learning models: From Table 5 the teaching learning model focus in mental processes (Learning and Teaching model in cloud: Signals learning, chaining,
Table 5: The teaching learning model focus in mental processes, learning by doing and social context as following

\begin{tabular}{|c|c|c|}
\hline Mental processes & Learning by doing & Social context \\
\hline Signals learning & Self-learning & $\begin{array}{l}\text { Brainstorms for } \\
\text { project based }\end{array}$ \\
\hline Chaining & Co-operative learning & $\begin{array}{l}\text { Planning their own } \\
\text { learning }\end{array}$ \\
\hline Verbal association & Project-based learning & Learning by doing \\
\hline Discrimination learning & Problem-based learning & Presentation \\
\hline Concept learning & Situation learning & Learning assessment \\
\hline Rule leaming & Group investigation & Modify actions \\
\hline Problem solving & Inquiry method & \\
\hline Creative thinking & New knowledge & \\
\hline \multirow{2}{*}{\multicolumn{3}{|c|}{$\begin{array}{l}\text { Reflective thinking } \\
\text { Thinking initiatives }\end{array}$}} \\
\hline & & \\
\hline
\end{tabular}

verbal association, discrimination learning, concept learning, rule learning, problem solving, creative thinking, reflective thinking and thinking initiatives) that it's might Learners' learning style: perceive-sensory, sensory channel, organization of information the learner prefer to process, the learner progress toward understanding. And Instructor's teaching style the type of information is emphasized by the instructor the mode of presentation is stressed, the presentation organized, the type of perspective is provided on the information presented. learning by doing (Activities and critical thinking model 
in cloud: Self-learning, co-operative learning, projectbased learning, problem-based learning, situation learning group investigation, inquiry method) that It's might learners' activities and critical thinking style: applying previous knowledge, doing new situations, solving problems, researching decisions and marking critical evaluations, deciding good thinking presenting in class and instructor's promoting class participant/controlling activity, effortful endeavor, designing in the task, instructor's outline organize his/her thoughts, find new ideas; mark simple charts; diagrams or tables to make organize course material; note and make an outline of concepts and social context (Construct knowledge and situation model in cloud: Brainstorms for project based; planning their own learning; learning by doing; new knowledge; presentation; learning assessment; modify actions) that it's might learners' interaction style: relationship between people environment; participation in communities of practice and utilization of resources; learners to collaborate and learn together. And instructors' create situation style: constructing new knowledge and understanding concepts, creativity and problem solving strategies strategies of learners will be further. Full participation in communities of practice and utilization of resources that include: construct new knowledge; understand concepts (Merriam and Caffarella, $1991)$.

\section{Part II}

Vocational education teaching and vocational education learning: Vocational education teaching and vocational education learning are focuses in three theories as in mental processes, learning by doing, social context all theories psychologies as in key ideas principles, teaching/learning activities/strategies, teaching learning environments, stages of instructional sequence. Teaching learning models.

In a vocational level focused on teaching both theory and practice instructor create operation conditional learning, Learner's create learning by doing and they had could to be self-discovery by them self. Vocational education may be classified as teaching procedural knowledge. This can be contrasted with declarative knowledge as used in education in a usually broader scientific field which might concentrate on theory and abstract conceptual knowledge, characteristic of tertiary education. Vocational education can be at the secondary or post-secondary level and can interact with the apprenticeship system. Increasingly, vocational education can be recognized in terms of recognition of prior learning and partial academic credit towards tertiary education as credit; however, it is rarely considered in its own form to fall under the traditional definition of higher education. The learner concerns the level and source of motivation for learning. According to sustaining motivation to learn is strongly dependent on the learner's confidence in his or her potential for learning. These feelings of competence and belief in potential to solve new problems are derived from first-hand experience of mastery of problems in the past and are much more powerful than any external acknowledgment and motivation. By experiencing the successful completion of challenging tasks, learners gain confidence and damming to help learners achieve learning objectives with effectiveness and efficiency as well as to help learners understand in a faster and stable way which complies with The National Education Act (1999) which reads: in organizing the learning process, educational institutions and agencies concerned shall provide training in thinking process, management, how to face various situations and application of knowledge for obviating and solving problems.

That is a view of learning that sees learners as active participants who construct their own understandings of the world around them. Using past experience and knowledge, learners make sense of the new information that they are receiving. In addition to the active nature of the learner, constructivist also asserts that meaningful learning occurs within an authentic situation with authentic learning tasks. In constructivist theory, learning is facilitated through social interaction, shared thought and decision making. This is to make Thai learners capable to develop themselves and compete with the world's knowledge-based economy.

Instructor design internet based education for learners as active participants who construct their own self understandings of the world around them. Using past experience and knowledge, learners make sense of the new information that they are receiving. The instructors use this framework to the students so they may learn by themselves. However, internet based Instructional Design Framework for Vocational Education (IDFVE) for from experts' opinions of selected psychology theories, namely Mental process, Learning by doing, and Social context classified by Teaching-learning models (Fig. 1).

- Signals learning, the stages of the learning process and Instructor signals learning (Conditional operated learning, giving information, objective, outcome, benefit in learning, title, subject, activity) create teaching criteria to suit the learners external conditions. Both instructor and learning how to do as for example:

- Chaining (Objective of learning, activities, event of learning, step by step of process learning, media instructional)

- Verbal association (Using process learning and instruction model)

- Discrimination, learning (Testing and feed black learning) 


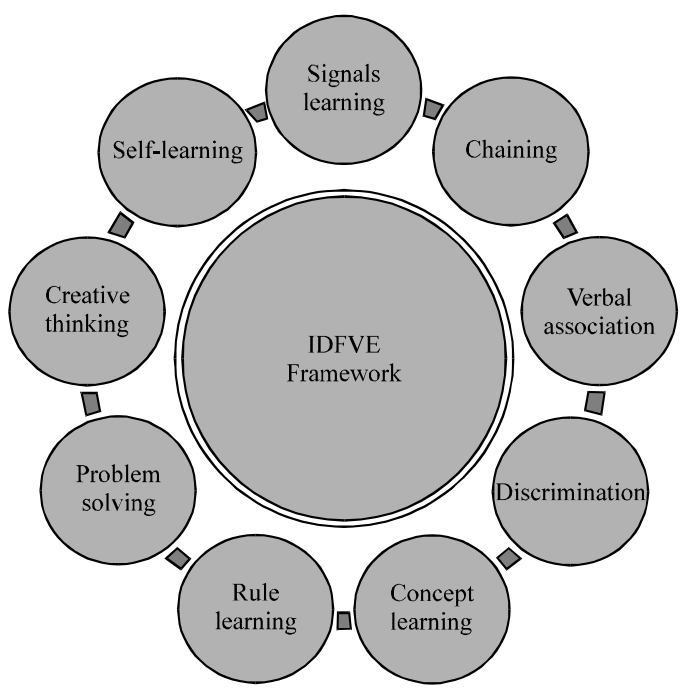

Fig. 1: The internet based Instructional Design Framework for Vocational Education (IDFVE) model

- Concept learning (Create task, conditional learning, method learning, stages teaching of learning process, select media, environments management)

- Rule learning (How to able to achieve in objectives of learning and conditional learning)

- Problem solving (Instruction model that it's for example programmed, tutorials, simulation Games drill and practices, test)

- Creative thinking, recognition, understanding of sustainability according to reflective thinking and thinking initiatives

- Self-learning (Learners can be learning by doing that it's planning, setting assumption investigation and solving problem by themselves)

\section{CONCLUSION}

In this research, the researchers have offered a framework and design process for the Internet-based environment. The implementation of IDFVE involved several steps including a consideration of various aspects of information, conceptual development, psychology theories and evaluation of the overall quality of the system environment.

In particular, the research aims to improvement of the design process and usability of the Internetbased environment. The study also confirmed that for Internet-based Instructional Design Framework for Vocational Education to be successful, various aspects of the online environment should be considered such as application domain knowledge, conceptual theory, psychology theories and evaluation about the overall quality of the design process.

\section{ACKNOWLEDGEMENTS}

This research has been done thanks to the funding of the Commission on Higher Education Ministry of Education, Thailand and thank to Department of Learning Innovation in technology, Faculty of Industrial Education and Technology, King Mongkut's University of Technology Thonburi, Bangkok Thailand. Also would like to express my great gratitude to Prof. Dr. David Coolkall and Mr. Suthee Ploisawaschai without all the assistance the completion this work would not have been possible. I would sincerely like to thank Dr. B.C. Mahapatra for him valuable comments and suggestion.

\section{REFERENCES}

Alexander, B., 2001. Youth organizing comes of age. Youth Today, 10: 16-18.

Attwell, G., 1997. Pressures for Change in the Education of Vocational Education and Training Personnel. In: Promoting Vocational Education and Training: European Perspectives, Brown, A. (Ed.). University of Tampere, Finland, pp: 107-122.

Bandura, A., 1986. Social Foundations of Thought and Action: A Social Cognitive Theory. Prentice Hall, Englewood Cliffs, New Jersey.

Blanchard, P.N. and J.W. Thacker, 2007. Effective Training: Systems, Strategies and Practices. 3rd Edn., Pearson Education, New Jersey.

Bruner, J.S., 1990. Acts of Meaning. Harvard University Press, Cambridge, Pages: 181.

Cobb, P. and L.P. Steffe, 2011. The constructivist researcher as teacher and model builder. A journey in mathematics education research. Math. Educ. Lib., 48: 19-30.

Conroy, C.A. and N.J. Walker, 2000. An examination of integration of academic and vocational subject matter in the aquaculture classroom. J. Agric. Educ., 41: 54-64.

Deway, J., 1933. How We Think. Forgotten Books, USA., ISBN: 1440049238

Dick, W. and L. Carey, 1996. The systematic design of instruction. Harper Collins, New York.

Gagnei, R.M., 1985. The Condition of Learning. Rinehart and Winston, New York, USA.

Hannafin, M.J. and S.M. Land, 1997. The foundations and assumptions of technology-enhanced studentcentered learning environments. Instruct. Sci., 25: $167-202$. 
Harman, K., and A. Koohang, 2005. Discussion board: A learning object. Interdisciplinary J. Knowledge Learning Objects, 1: 67-77.

Honebein, P., 1996. Seven Goals for the Design of Constructivist Learning Environments. In: Constructivist Learning Environments, Wilson, B. (Ed.). Educational Technology Publications, New Jersey, pp: 17-24.

Hung, D., 2001. Constructivism and E-learning: Balancing between the individual and social level if cognition. Educ. Technol., 41: 40-44.

Jetin, B., 2006. The cognitive international division of labour hypothesis: What possible effects for thai labour and education? J. Educ., 33: 1-45.

Jonassen, D.H., 1983. Designing Constructivist Learning Environments. In: Instructional Design Theories and Models: A New Paradigm of Instructional Technology, Reigeluth, C.M. (Ed.). Lawrence Erlbaum Associates, Mahwah, New Jersey, ISBN: 0805828591, pp: 215-241.

Kafai, Y. and M. Resnick, 1996. Constructionism in Practice: Designing, Thinking and Learning in a Digital World. In: Lawrence Erlbaum, New Jersey, pp: 71-96.

Koohang, A. and K. Harman, 2005. Open source: A metaphor for E-learning. Inf. Sci. Int. J. Emerg. Transdiscip., 8: 75-86.

Koohang, A., L. Riley and T. Smith, 2008. E-learning and constructivism: From theory to application. J. E-Learning Learning Objects, 5: 91-109.

Likert, R., 1932. A technique for the measurement of attitudes. Arch. Psychol., 140: 1-55.
Marr, M.J., E.W. Thomas, M.R. Benne, A. Thomas and R.M. Hume, 1999. Development of instructional systems for teaching an electricity and magnetism course for engineers. Am. J. Phys., 67: 789-802.

Merriam, S. and Caffarella, 1991. Learning in Adulthood. Jossey-Bass, San Francisco, pp: 138.

Muzio, J.A., T. Heins and R. Mundell, 2002. Experiences with reusable E-learning objects: From theory to practice. Internet Higher Educ., 5: 21-34.

Phillips, R., 2005. Pedagogical, Institutional and Human Factors Influencing the Widespread Adoption of Educational Technology in Higher Education. In: Balance, Fidelity, Mobility: Maintaining the Momentum, Goss, H. (Ed.). Queensland University of Technology, Brisbane, Australia, pp: 541-549.

Piaget, J., 1972. To Understand is to Invent. The Viking Press Inc., New York.

Sangsawang, T., 2006. Comparison of selected psychology theories as in gagne's, constructivism and constructionism. Proceedings of the 4th International Conference on Developing Real-Life Learning Experiences: Education Reform through Performance-Based Learning, July 13-14, 2006, KMITL, Bangkok, Thailand, pp: 327-328.

Tan, K., V. Dawson and G. Venville, 2008. Use of cognitive organizers as a self-regulated learning strategy. Educ. Res., 18: 183-207.

Taylor, J., 1996. Piagetian perspectives on understanding children's understanding. Childhood Educ., 72: 58-59.

The National Education Act, 1999. Office of the national education commission. Constructivism and Constructionism. Bangkok, National Education Act B.E. 2542.

Velde, C. and T. Cooper, 2000. Students perspectives of workplace learning and training in vocational education. Educ. Train., 42: 83-92. 